\title{
Employee Need Satisfaction and Positive Workplace Outcomes: The Role of Corporate Volunteering
}

\section{Debbie Haski-Leventhal ${ }^{1, *}$, Andrew Kach ${ }^{2}$ and Mehrdokht Pournader ${ }^{1}$}

1. Macquarie Graduate School of Management

2. Willamette University’s Atkinson Graduate School of Management

\section{Associate Professor Debbie Haski-Leventhal}

Affiliation: Macquarie Graduate School of Management

Address: 99 Talavera Rd., North Ryde, NSW, 2109, Australia

Phone number: +61-2-98507860

Email: debbie.haski-leventhal@mgsm.edu.au

Debbie Haski-Leventhal is a Professor of Management at Macquarie Graduate School of Management (MGSM) and the Program Director of the Master of Social Entrepreneurship. She has published widely on volunteering and corporate social responsibility and co-wrote the United Nations State of the World Volunteerism Report. Her work has been published in NVSQ, Human Relations, Voluntas and Journal of Business Ethics.

\section{Dr Andrew Kach}

Affiliation: Willamette University's Atkinson Graduate School of Management

Address: 900 State St., Salem, OR 97305, USA

Phone number: +1-503-370-6884

Email: apkach@willamette.edu

Andrew Kach is an Assistant Professor of Operations and Supply Chain Management at Willamette University’s Atkinson Graduate School of Management. His research focuses on sustainable global supply chain issues. His work has been published at Decision Sciences, Organizational Research Methods, the Journal of Business Logistics, and elsewhere.

\section{Dr Mehrdokht Pournader}

Affiliation: Macquarie Graduate School of Management

Address: 99 Talavera Rd., North Ryde, NSW, 2109, Australia

Phone number: +61-2-98509036

Email: mehrdokht.pournader@mgsm.edu.au

Mehrdokht Pournader is a lecturer of Operations and Supply Chain Management at Macquarie Graduate School of Management. Her research focuses on risk management in operational and behavioral contexts as well as managing risks associated with companies' triple bottom lines. Her work has been published in International Journal of Production Economics, Supply Chain Management: An International Journal, and Journal of Business Ethics.

Author(s)' Note: The authors would like to thank the MGSM CSR Partnership Network whose members contributed to the research design and data collection. In particular, we are grateful to the Johnson \& Johnson Family of Companies Australia for being the lead partner of the Network and supporting this research. 


\title{
Employee Need Satisfaction and Positive Workplace Outcomes: \\ The Role of Corporate Volunteering
}

\begin{abstract}
Corporate volunteering (CV) is a fast-growing trend in voluntary action. As an increasing number of not-for-profit organizations receive help from corporations in the form of $\mathrm{CV}$, it is important to build a 'business case' for this important collaboration and to better understand why employees volunteer through their workplace. Borrowing from the existing literature and selfdetermination theory (SDT), we examine how satisfaction of psychological needs through CV affects job satisfaction and affective commitment. Drawing on a survey of 4,127 employees, volunteers show significantly higher rates of job satisfaction and affective commitment compared to non-volunteers. Among employees who participate in CV, relatedness and competence need satisfaction through CV positively affect job satisfaction and affective commitment. The results of this study contribute to the body of knowledge on CV, and SDT and provide practical implications for companies and not-for-profit organizations.
\end{abstract}

Keywords: corporate volunteering, affective commitment, job satisfaction, self-determination theory, need satisfaction 


\section{Introduction}

In recent years, corporate volunteering $(\mathrm{CV})$ has become a growing trend in voluntary action (Wilson, 2012) as it has allowed employees to combine volunteering efforts with their employment (Haski-Leventhal, Meijs, \& Hustinx, 2010). CV programs, which are supported and developed by employers to encourage employee voluntary activities outside the organization (Kotler \& Lee, 2005), allow employees to provide their knowledge and/or skills to the community on company time, as part of the employer's community service, outreach, or social responsibility activity (de Gilder, Schuyt, \& Breedijk, 2005).

While CV serves many nonprofit organizations (NPOs), it also serves the for-profits and the individual employees, particularly through employee engagement and positive workplace outcomes. Through spillover effects, volunteering can provide purposefulness and create a sense of meaningfulness at work (Rodell, 2013) and thus indirectly increase affective commitment and job satisfaction. CV has the potential to strengthen employees' affective commitment to an organization by changing the way employees view themselves and the organization (Grant, Dutton, \& Rosso, 2008).

While there is a growing body of literature showing a positive relationship between CV and positive workplace attitudes (e.g., de Gilder et al., 2005; Peterson, 2004; Plewa, Conduit, Quester, \& Johnson, 2015) we still lack knowledge on the psychological mechanisms that underlie the process and lead to these outcomes. As Grant (2012, p. 591) explicitly argued: "Despite the importance of the sustained participation of employees in corporate volunteering programs, surprisingly little research has examined the factors that affect it”.

As CV is an activity which lies between leisure and work, leveraging theory from organizational psychology could help shed light on these issues. Drawing on self-determination theory (SDT) 
(Deci \& Ryan, 1985; Ryan \& Deci, 2000), we argue that the satisfaction of psychological needs through participation in CV will contribute to increased employee satisfaction and commitment.

The present research addresses the following questions: Does CV participation lead to higher levels of affective commitment and job satisfaction? Is satisfaction of relatedness and competence needs through CV associated with affective commitment and job satisfaction? Do positive employee attitudes towards their employer's corporate social responsibility (CSR attitudes) strengthen the relation between need satisfaction through CV and affective commitment and job satisfaction?

\section{Literature Review and Hypotheses}

\section{Corporate Volunteering and SDT}

Despite the evidence that employees are motivated to make a positive difference in other people's lives, the literature is relatively silent about the sources of this motivation (Grant, 2007). There is a vast amount of empirical data on why people volunteer in general (Clary et al., 1998; Cnaan \& Goldberg-Glen, 1991; Wilson, 2012), but a lack of knowledge on motivations to volunteer through the workplace. While most studies on motivation to volunteer use the Volunteer Function Inventory (VFI) (Clary, Snyder, \& Stukas, 1996), the motivation to participate in CV cannot be solely explained using this framework. VFI includes six functions or needs that volunteering can help address (values, understanding, enhancement, career, social and protective), but they were not designed to explain why people would choose to volunteer through their workplace as opposed to doing it as a private activity. As CV is an activity that combines volunteering and work to address motivation and need satisfaction of both leisure and labor, a 
framework of organizational psychology, such as SDT, could help us better understand this phenomena in a novel way.

SDT (Deci \& Ryan, 1985; Ryan \& Deci, 2000; Ryan \& Deci, 2001) is a theory of human motivation which proposes that when basic psychological needs are satisfied within a context (organized work), employees are more likely to be motivated through meaning and enjoyment (autonomous motivation) as opposed to being motivated through rewards and punishments (controlled motivation). Extending SDT to CV could be justified since it is a means to satisfy psychological needs in the workplace, which could in turn impact workplace outcomes such as affective commitment and job satisfaction (Gagné \& Deci, 2005; Greguras \& Diefendorff, 2009). Several scholars used the SDT to understand volunteering (Millette \& Gagné, 2008) and corporate volunteering (Grant, 2012; van Schie, Gautier, Pache, \& Güntert, 2018) as it is not only novel, but offers a very relevant framework.

SDT proposes that humans thrive when they feel competent, autonomous, and related to others around them (Deci \& Ryan, 2000). The need for autonomy implies acting with a sense of volition, having the experience of choice and feeling like the initiator of one’s own actions. Competence refers to feeling like one can master and accomplish tasks. The need for relatedness means to feel connected with others and to have meaningful relationships. As a large body of empirical evidence has shown that autonomy, competence, and relatedness are indeed related to autonomous motivation and well-being (Ryan \& Deci, 2000) these needs have been argued to be necessary for growth and well-being.

CV incorporates the components to satisfy basic psychological needs for autonomy, competence, and relatedness (see, Bidee et al., 2013; Gagné, 2003; Haivas, Hofmans, \& Pepermans, 2012; Oostlander, Güntert, Schie, \& Wehner, 2014). First, CV is usually a discretionary workplace 
behavior which falls under extra-role performance (Rupp, Shao, Thornton, \& Skarlicki, 2013), and employees usually have autonomy to choose whether to volunteer and sometimes choose which community organization to volunteer for (Barman, 2007). Second, CV has the potential to offer employees the chance to do something different, thereby learning or practicing new or different skills (Mirvis, 2012) thus offering employees the chance to enhance their competence (Sundeen \& Raskoff, 1994). Third, CV offers an additional context for meeting new people and forging new meaningful relationships, thereby fulfilling the need for relatedness (Grant, 2012; Haski-Leventhal \& Cnaan, 2009). Hence, CV may be an alternative source of need satisfaction when the needs for competence, autonomy, and relatedness are not met in one's paid job or have an additive effect when these needs are met (Grant, 2008; Rodell, 2013). As Grant (2007) explained, employees experience autonomy in acting freely to benefit others, competence in successfully helping others, and relatedness in connecting their actions to outcomes that matter in the lives of other people.

As current research evidence shows, employee-related benefits of CV were found to be linked to positive workplace attitudes including job satisfaction and affective commitment among others (de Gilder et al., 2005; Peterson, 2004; Plewa et al., 2015). Paço and Nave (2013) provided evidence that satisfaction with CV experience led to overall job satisfaction, but with a weak/moderate relation between volunteers' motivations and satisfaction. Employees are more likely to perceive the benefits of volunteering (to them and to others) when these benefits outweigh the related costs to the employees (Handy et al., 2000). In the work domain and according to SDT, satisfaction of basic psychological needs (i.e., autonomy, competence, and relatedness) has been shown, through meta-analytic findings, to be highly related to both job satisfaction and to affective commitment and to be promoted through workplace factors, such as 
job design and leadership (Van den Broeck, Ferris, Chang, \& Rosen, 2016). Thus, given CV’s capability of satisfying the aforementioned basic psychological needs of employees, it can in turn enhance the positive workplace attitudes of employees. Therefore, we suggest the following: H1a Gaining competence through participating in CV is positively related to affective commitment.

H1b Gaining competence through participating in $\mathrm{CV}$ is positively related to job satisfaction. H2a Gaining relatedness through participating in CV is positively related to affective commitment.

H2b Gaining relatedness through participating in CV is positively related to job satisfaction.

It is worth mentioning that $\mathrm{CV}$ is usually construed as a highly autonomous and extra-role behavior and a part of organizational citizenship behavior (Mirvis, 2012; Rupp et al., 2013). In the context of the current study (ten large Australian companies) CV was autonomous (practiced willingly by most employees) and therefore it presented a unique research opportunity to examine relatedness and competence need satisfaction through an autonomous behavior. Furthermore, we have filtered our sample to only include people who had the autonomy to participate in this activity and choose the NPO for which they volunteered to assure autonomy, as will be explained in the methods section.

\section{The Moderating Role of CSR Attitudes}

Attitudes reflect the individual's overall positive or negative evaluation of a target, based on the person’s feelings or emotions about the target (Morris, 1997; Steers, 1981). Consequently, employees' attitudes toward their employer's CSR (or 'CSR attitudes') reflect their positive or 
negative evaluation of CSR in general (e.g., how important it is for them) and of their employer's efforts to be more responsible towards the community, the environment and other stakeholders (Crites, Fabrigar, \& Petty, 1994).

According to the CSR Congruence Model (Haski-Leventhal, Roza, \& Meijs, 2015), when an alignment exists between employees’ and employers' socially responsible behavior (including participation in $\mathrm{CV}$ ) and identity (which includes positive CSR attitudes), positive outcomes may emerge, such as employee engagement, job satisfaction and commitment. Indeed, previous research has demonstrated a well-established link between CSR attitudes and positive workplace outcomes (see among, Aguilera, Rupp, Williams, \& Ganapathi, 2007; Aguinis \& Glavas, 2012; Brammer, Millington, \& Rayton, 2007; Heslin \& Ochoa, 2008). As one of the fastest growing aspects of CSR, surprisingly the synergic effect of CV and CSR attitudes on the positive workplace attitudes are yet to be explored (Plewa et al., 2015). The body of the literature has so far mainly focused on explaining how companies' support for CV could impact their CSR image and help them gain competitive advantage in the market (e.g., Basil, Runte, Easwaramoorthy, \& Barr, 2009; Plewa et al., 2015).

Based on the above literature review, CV is empirically linked to positive workplace outcomes (de Gilder et al., 2005; Peterson, 2004; Plewa et al., 2015) and CSR attitudes are linked to positive workplace outcomes, but it is important to see if CSR attitudes are an independent variable or could moderate the connection between need satisfaction through CV and positive workplace outcomes. According to the theory of planned behaviour (Ajzen, 1991), the link between motivation and behavior is moderated by attitudes and subjective norms and as such, it is possible that employees with positive CSR attitudes will have a stronger link between need satisfaction and workplace behavior. 
Considering this, we hypothesize that need satisfaction through participation in CV will be more strongly related to job satisfaction and affective commitment when employees have positive attitudes toward CSR.

H3a CSR attitudes strengthen the relation between competence [through CV] and affective commitment

H3b CSR attitudes strengthen the relation between competence [through CV] and job satisfaction

H4a CSR attitudes strengthen the relation between relatedness [through CV] and affective commitment

H4b CSR attitudes strengthen the relation between relatedness [through CV] and job satisfaction

The hypotheses above are illustrated as structural models in Figure 1a and Figure 1b.

--- Insert Figure 1a and Figure 1b about here ---

\section{Method}

\section{Procedure}

An online cross-sectional survey was designed and sent out to employees in ten large corporations in Australia, some Australian based (such as a leading Australian bank) and some multi-nationals (such as leading pharmaceutical or food companies). The companies were all part of a partnership network created by the chief investigator, which included for-profits, NPOs, and governmental departments. At the time of the survey, all ten companies had autonomous CV 
programs, in which employees could choose to participate, and in some cases could choose the charity organization. Seven of the ten companies provided paid leave days (between 1-5 days a year) for volunteering so employees could volunteer and claim back the hours they gave. The research questions, design and instrument were developed in consultation with members of the network, and the initial data were presented to the members who discussed the results and provided some interpretation. A pre-test was conducted with a group of 20 employees representing each of these companies, after which some changes were made to better align measures with theory and practice.

\section{Sample}

During May-June 2013 the online survey was distributed by the companies to a total of 35,980 employees via email, to which 4,127 employees responded, resulting in a response rate of $11.47 \%$. Over one half (58\%) of the survey participants were females and $83 \%$ were full time workers. As for job level, 32\% were at a professional job level, 27\% were middle managers, $19 \%$ were in administration, $8 \%$ were senior managers, and $8 \%$ were junior executives, with $6 \%$ ‘other’. Regarding income levels, 45\% were earning \$75,000-\$150,000; 27\% were earning $\$ 35,001-\$ 75,000 ; 14 \%$, over $\$ 150,000 ; 11 \%$ preferred not to say and $3 \%$ were earning less than $\$ 35,000$. Nearly $26 \%$ of survey respondents participated in CV in the 12 months prior to this survey, resulting in a sample of 1,068 . From that sub-sample, the data was screened for those who reported that their engagement in CV was autonomous, resulting in a final usable sample of 911.

We conducted an analysis juxtaposing those who participated in corporate volunteering efforts with non-volunteers with regards to CSR attitudes and our two outcome variables using t- 
tests. Findings showed a highly significant difference between volunteers and non-volunteers on CSR attitudes $(\mathrm{p}<.001)$ and between both outcome variables respectively $(\mathrm{p}<.001)$, providing evidence that volunteers in our sample had higher job satisfaction and affective commitment levels than their non-volunteering counterparts (see Table 1).

--- Insert Table 1 about here ---

\section{Measures}

All multi-item variables were adopted from the existing literature and measured using a fivepoint Likert scale (unless indicated otherwise).

Need satisfaction through CV (competence and relatedness). Despite the presence of scales to measure basic need satisfaction constructs (Baard, Deci, \& Ryan, 2004; Vansteenkiste et al., 2007), in this study we were interested in measuring the competence and relatedness constructs separately considering that we needed to delve deeper into understanding their effect on positive workplace attitudes. Thus, we defined separate measures for competence and relatedness that are relevant to the context of $\mathrm{CV}$.

For the following two scales, employees were asked: how important were the following reasons in your decision to join workplace volunteering (from 1 - not at all important to 5 - very important). It is worth noting that due to the lack of studies in the literature with measures adjusted for need satisfaction through CV, the authors proposed and assessed customized measures to address this issue in addition to using existing ones (McDonald, 2007).

Competence was measured through items that are specifically relevant to the context of CV and according to Deci and Ryan (2000, p. 252) would results into “cognitive, motor, and social growth” (Alpha: .796, AVE: .624): it makes work more meaningful to me; it provides an 
opportunity to use my professional skills to help others; and it provides an opportunity to develop new skills. Relatedness was measured via items corresponding to "the desire to feel connected to others” (Deci \& Ryan, 2000, p. 231) and the psychological need to be part of a group (here volunteering group of co-workers) (Alpha: .714, AVE: .543): My colleagues volunteer; my boss volunteers; it is fun [to be part of the volunteering social group] and it is good to know that a lot of people can do more together.

Autonomy. Respondents were asked if they were able to select the NPO for which they volunteered or if their supervisor or company chose it for them. Those that depicted that they had freedom to choose their charity $(\mathrm{n}=911)$ were retained in the sample. Those who indicated that they did not have freedom to choose $(n=157)$ were removed.

CSR attitudes. Six CSR attitudes were assessed via 5-point scales based on Haski-Leventhal (2013). Scales were labeled from Strongly Disagree (1) to Strongly Agree (5). Items included positive attitudes such as It is important for me to work for a company that is involved in the community; my company is involved in the community primarily to make a difference and reverse scales such as Work and giving should be separate (Alpha: .710, AVE: .496).

Affective commitment. We measured affective commitment to the company with six items from the affective commitment scale reported by Meyer, Allen, and Smith (1993). Items were scales from Strongly Disagree (1) to Strongly Agree (5) and included the following: I would be happy to spend the rest of my career in this organization; I really feel as if this company's problems are my own; and reverse scales such as I do not feel a strong sense of 'belonging' to my organization and I do not feel 'part of the family' in my organization (Alpha: 0.818, AVE: .589).

Job satisfaction. Job satisfaction was measured based on the motivation factors and hygiene factors of Herzberg, Mausner, and Snyderman (1959) and Herzberg (1966) with some 
amendments and additions such as satisfaction with the employer's social responsibility. Employees were asked how satisfied are you with the following aspects of your work and items included: your role; your salary; your relationship with others in the workplace; your achievements; the organization's social responsibility and sustainability; and leisure activities (Alpha: .813: AVE: .488).

Control variables. Several control variables were found to predict the relationship between CSR attitudes and affective commitment in previous research, such as gender, education, income and age (Brammer et al., 2007; Peterson, 2004; Skudiene \& Auruskeviciene, 2012). These variables were also found to be related to volunteering (Wilson, 2012) and CV (for a recent review see Rodell, Breitsohl, Schröder, \& Keating, 2016). We therefore used them as control variables for this study. In addition, we wanted to control for the time devoted to volunteering (volunteer hours) as it is possible that the more people volunteer through their workplace, the stronger the relationship is going to be between $\mathrm{CV}$ and workplace outcomes.

\section{Convergent Validity and Measurement Adequacy}

Common method bias. The design of this study was constructed in order to minimize method variance. Following the four-step validation process (Diamantopoulos \& Winklhofer, 2001), a group of 20 practitioners were contacted to assess the content and indicator specifications.

Questionnaire design and survey items were carefully constructed, taking precautions to avoid ambiguous wording and double-barreled questions. Additionally, the aforementioned pilot study was included in order to reduce design flaws and ensure that the variables under consideration behaved according to their expected measure. 
The latent common method factor test was employed in order to investigate potential singlerespondent bias (Podsakoff, MacKenzie, Lee, \& Podsakoff, 2003), including all independent and dependent variables, through a confirmatory type factor analysis to verify whether significant method variance was present. The data indicated that squaring the resulting regression weights accounted for $8.4 \%$ common variance. Moreover, including a marker variable (Williams, Hartman, \& Cavazotte, 2010) “years of volunteering experience” which was theoretically unassociated with the constructs under consideration, resulted in a decrease to $0.5 \%$ common variance explained by the marker model and $\chi^{2}$ increase of 1257.98 , suggesting no notable common method bias concerns.

Multicollinearity analyses were conducted based on an examination of the variance inflation factor (VIF) for each variable, with a maximum threshold of 10 for item elimination (Hair, Black, Babin, \& Anderson, 2010). The highest value detected was 1.35 (for the competence variable), which falls well below even the more stringent threshold reported in the literature of 5 . While the results of these tests do not remove the potential for common method bias, they provide supporting evidence that correlations and relationships between items are not primarily driven by common method bias.

Non-response Bias. Following recommendations from Koufteros, Rawski, and Rupak (2010), a discriminatory analysis split the sample evenly between two randomly assigned groups to check for differences between the variables in each group using the Kolmogorov-Smirnov test (Shrout \& Bolger, 2002). The results from this analysis detected no significant differences. Additionally, early and late respondents were separated equally into two separate groups and a multivariate ttest was conducted, comparing the responses of the two groups. The aforementioned test indicated that no significant differences exist between the samples, which met our expectations 
given the short two-month time span in which the data was collected. This test signifies that the two groups came from the same sample population, in support of the robustness of the findings. Confirmatory factor analysis. Prior to conducting the factor analysis, each scale was examined and tested for instrument reliability. Data was split evenly into two groups containing circa 455 responses each, as recommended by Podsakoff et al. (2003) when applying the split-half technique. No significant differences were discovered between the variable reliabilities within the two groups of data. Additionally, Spearman-Brown and Guttman Split-half techniques were applied to assess further consistency and instrument reliability. The resulting values (see Appendix A) did not exceed the minimum standard purported by scholars (Hair et al., 2010). Lastly, discriminant validity of the model was further evaluated by assessing the average variance extracted (AVE) for each scale, which were close to or exceeded the recommended minimum of .50 (Fornell \& Larcker, 1981) and greater than the squared correlations with other constructs (see Appendix A).

Confirmatory factor analysis (CFA) was conducted on the previously established scales within the study to examine the validity of the measures (Anderson \& Gerbing, 1988). CFA provides regimented and straightforward interpretations of unidimensionality (Blunch, 2008; Bollen \& Stine, 1992). The heuristic for minimal acceptable scale reliabilities is .70 for existing scales (Nunnally \& Bernstein, 1994). Results indicated that all of the coefficient alpha values were above the .70 cutoff value for pre-existing scales (see Appendix A). Additionally, goodness of fit and chi-squared data was collected and reviewed. As is noted (see Appendix A), the goodness of fit results for the previously established scales exceed the satisfactory minimum required cutoff values of close to or above .90 for CFI (.924), TLI (.910) and IFI (.924), close to 
or below .06 for RMSEA (.051), and close to or below .08 for SRMR (.053) (Hu \& Bentler, 1999).

According to the CFA results, all factors loaded appropriately (Appendix A). Loading values above .45 are considered acceptable for items within each scale, while higher loading values indicate a better fit (Hu \& Bentler, 1999). Items that did not load into any predetermined factor were removed from the analysis (indicated by a dashed line within Appendix A). One cross loading was detected with the Affective Commitment item I would be very happy to spend the rest of my career with this company, which also loaded at 0.426 into the Job Satisfaction category. Given the pre-established nature of these scales, and the low result of the cross-loading score, we decided to retain this item for sake of parsimony. Additionally, running the analyses with this item removed did not provide any significant difference in the results; therefore, we did not see any harm in retaining it.

\section{Results}

The means, standard deviations, and correlations for the variables utilized throughout the study are presented in Table 2. The descriptive statistics did not reveal any concerning relationships. As expected, employee age, employee salary, and employee gender were all positively correlated. Affective commitment and job satisfaction were significantly correlated (.58; $p<$ .01). Other averages and standard deviations resided within normal expected ranges. All of the Likert scale type variables demonstrated means around the center, with standard deviations exceeding 0.50. All skewness and kurtosis values for the variables under consideration fell within the recommended range (+/- 2.99) (Hair et al., 2010).

--- Insert Table 2 about here --- 


\section{Direct Effects of Competence and Relatedness on Affective Commitment and Job}

\section{Satisfaction}

We conducted a Multivariate Linear Regression analysis in SPSS 24 to test our hypotheses. We estimated the model coefficients using ordinary least squares regression, for continuous outcomes, which generated direct and indirect effects. To achieve this, we ran a single model, testing both dependent variables (i.e., affective commitment and job satisfaction) in tandem, and reported the output of the direct and indirect effects respectively. We entered the control variables, independent variables (competence and relatedness), and moderator variable (CSR Attitudes) into the regression model on separate steps. All independent and moderator variables were mean centered before creating the interaction variables and conducting the regression analyses (Liu, Eng, \& Ko, 2013).

Table 3 provides the results of the Multivariate Linear Regression analyses. H1a posits that as competence increases, affective commitment will be positively impacted. The significantly positive path coefficient for competence on affective commitment $(B=.078, p<.01)$ provides support for H1a. Similarly, H1b depicts that as competence increases it will have a positive impact on job satisfaction. The positively significant path coefficient for competence on job satisfaction $(B=.052, p<.05)$ provides support for H1b.

H2a posits that relatedness will have a positive impact on affective commitment. The significantly positive path coefficient for relatedness on affective commitment $(B=.089, p<.01)$ provides support for H2a. Similarly, H2b depicts that relatedness will have a positive impact on job satisfaction. The significantly positive path coefficient between relatedness and job satisfaction $(B=.092, p<.001)$ provides support for H2b.

--- Insert Table 3, Figure 2a, and Figure 2b about here --- 


\section{Moderation Effects}

The moderating effect of CSR attitudes on the relationship between competence and affective commitment was positive and significant $(B=.135, p<.001)\left(\right.$ Simple Slope $\mathrm{Z}_{\mathrm{High}}: t=3.526, p=$ .000) (Simple Slope $\mathrm{Z}_{\text {Low }} t=3.646, p=.000$ ); providing support for H3a (see Figure 3a). The moderating effect of CSR attitudes on the relationship between competence and job satisfaction was positive yet non-significant; failing to provide support for H3b.

The moderating effect of CSR attitudes on the relationship between relatedness and affective commitment was negative and non-significant, failing to provide support for H4a. Moreover, the moderating effect of CSR attitudes on the relationship between relatedness and job satisfaction was significantly negative $\left(B=-.077, p<.05\right.$ ) (Simple Slope $\mathrm{Z}_{\mathrm{High}}: t=-1.447, p=.148$ ) (Simple Slope $\mathrm{Z}_{\text {Low: }} t=-1.234, p=.218$ ), failing to provide support for H4b (see Figure 3b).

--- Insert Figures 3a and 3b about here ---

\section{Discussion}

The aim of this study was to understand the psychological mechanisms through which employees’ participation in CV is related to positive workplace outcomes, such as affective commitment and job satisfaction. Based on the existing literature and SDT, we hypothesized that satisfying the needs for competence and relatedness through participation in CV (as an autonomous activity by the employees) will have a direct and positive relationship with affective commitment and job satisfaction. We further hypothesized that employees’ perceptions of their employer’s CSR will strengthen this relationship.

The present research demonstrated that CV participation was indeed positively and significantly related to job satisfaction and affective commitment. More importantly, 
accumulating the results of both models showed that satisfying the need for both competence and relatedness through $\mathrm{CV}$ was positively linked to affective commitment and job satisfaction. This finding is interesting, as affective commitment is emotional and focused on the 'other' (for example, seeing the organizational problems as my own), whereas job satisfaction is more rational and it based one’s role and achievements (Borzaga \& Tortia, 2006). Despite this fundamental difference in the nature of affective commitment and job satisfaction, CV can positively affect both and help organizations retain more satisfied and committed employees.

As for the moderating role of CSR attitudes, employees who felt strongly about CSR were more likely to be committed to their workplace if they could satisfy their competence need through CV. This could be attributed to a synergistic effect, where employees with positive CSR attitudes discover that developing and utilizing their skillsets through CV is an opportunity provided by the employer to which they show higher levels of affective commitment. Interestingly, strong CSR attitudes weakened the relationship between relatedness and the positive workplace outcomes, because employees with such attitudes who participate in CV might desire to see CV that is focused on the community needs and not on team building goals (Grant, 2012).

Our findings regarding the positive effect of satisfying the needs for relatedness and competence through $\mathrm{CV}$ on affective commitment are aligned with the existing literature (Aguilera et al., 2007; Brammer et al., 2007; Heslin \& Ochoa, 2008; Peterson, 2004). As for job satisfaction, similar to existing literature, our study also showed that CV could be related to job satisfaction (Heslin \& Ochoa, 2008; Trevino \& Nelson, 2004; Valentine \& Fleischman, 2008).

The article contributes to both theory and practice. Firstly, it contributes to SDT by expanding applications to the CV context. We showed that relatedness and competence needs 
can be satisfied through engagement in CV. Secondly, we provide a new model on the impact of need satisfaction via CV on employees and employers. While there are many studies and conceptual papers on the benefits of CSR and CV (see, Aguinis \& Glavas, 2012), we still lack knowledge on the psychological mechanisms underlying this relationship. CV contributes to positive workplace outcomes because it meets the needs of employees to master their work and have meaningful relationships with their peers. CV can help build employee competencies, particularly when it is skill-based volunteering (Mirvis, 2012) and creates strong bonds in the workplace (Grant, 2012; Haski-Leventhal \& Cnaan, 2009).

\section{Implications for Practice}

Many companies strive to engage their employees, increase their commitment and satisfaction in order to improve performance and retention. To do so, it was previously suggested in the literature (Van den Broeck et al., 2016) that meeting employee needs for autonomy, relatedness and competence could help achieve these highly desirable goals for employers and employees alike. Our study shows that one effective way of achieving the above, is involving employees in the company's CSR through CV, which can be an alternative source for positive workplace or even have an additive effect, as was shown in our study. Participation in an autonomous activity, such as CV, in which employees build their relationship with their peers and develop their skills while benefiting the community, can lead to aforementioned positive results for the company, their employees and society at large. CV is often being used as a mean for team building and our research shows that it can be an effective way to meet employees’ social needs (Grant, 2012). In addition, CV can help employees and managers strengthen their relationship and create lasting bonds that can, in turn, serve their job performance. However, it should be noted that for CV to 
be effective, particularly among employees who feel strongly about CSR, it needs to be meaningful, impactful and to address the needs of the community, instead of a mere teambuilding exercise.

This study helps to develop a rationale for CV which can be used by NPOs to promote collaborations with for-profits and benefit from it. While there are obvious benefits to the community, such as skilled human resources and capital, often companies desire the benefits to the employees and the organization as well (Liu et al., 2013). NPOs and for-profits need to design CV programs that allow employees to meet their own needs of autonomy (e.g., allowing them to choose their own charity); relatedness (e.g., team volunteering) and competencies (e.g., skill based CV, see Mirvis (2012)) while first and foremost meeting the needs of the community.

\section{Limitations and Direction for Future Research}

While our study offers important contributions to practice and theory it also has some limitations. Firstly, we did not incorporate ‘autonomy' directly as a separate construct for need satisfaction assessment in our model. This was mainly due to this understanding that CV is inherently an autonomous task and more importantly for most employees in Australia participating in $\mathrm{CV}$ is completely autonomous. However, in order to make sure that we only included responses in our model that represented autonomous CV, we used a buffer question as explained in the method section. Nevertheless, using autonomy as a separate construct in our proposed model could have provided insights about its relationship with the dependent variables (i.e., job satisfaction and affective commitment) for organizational contexts that represent various levels of autonomy in participating in CV. Furthermore, we asked participants about their motivation to join (how important were the following reasons in your decision to join 
workplace volunteering?"), but as the aim was to examine need satisfaction we could have asked more directly about their need satisfaction through their actual experiences (e.g., "Please read each of the following items carefully, thinking about how it relates to workplace volunteering, then indicate how true it is for you."). Future research on SDT and motivation to volunteer could ask directly about autonomy need satisfaction and use this wording.

Secondly, the sample was only confined to Australian employees. Additional comparative studies on an international scale are required to validate the results obtained by this study. Finally, it is possible that employees who participate in CV have higher levels of commitment and satisfaction to begin with, which is possibly why they participate in such extra-role behavior. However, our sample only includes CV participants and our model reports on more complex relationships between the components of need satisfaction through CV and positive workplace outcomes; hence the exclusion of non-volunteers from the analyses. Non-volunteers had to be excluded as they could not report on need satisfaction without being too hypothetical. It is not uncommon for studies that look at both volunteers and non-volunteers, to ask different questions (e.g., Dury et al., 2014; Haski-Leventhal et al., 2018), but future research could compare need satisfaction for both groups by asking questions that can be answered by non-volunteers too.

\section{Conclusion}

While there are several studies reporting on the relationship between CSR, CV and employee positive workplace attitudes (including affective commitment and job satisfaction), this paper is the first to analyze the underlying psychological mechanisms through which employee participation in CV can lead to positive workplace outcomes. If this relationship is indeed due to self-determination need satisfaction, the implications for further research and to business practice 
could be immense. CV is an effective way to provide employees with a sense of autonomy, relatedness and competence while also assisting the community. 


\section{APPENDIX A}

\section{Confirmatory Factor Analysis}

\begin{tabular}{|c|c|c|c|}
\hline Scales and Items & $\begin{array}{c}\text { Spearman } \\
\text { Brown }\end{array}$ & $\begin{array}{l}\text { Gutmann } \\
\text { Split-half }\end{array}$ & $\begin{array}{l}\text { Factor } \\
\text { Loading }\end{array}$ \\
\hline $\begin{array}{l}\text { Corporate Social Responsibility Attitudes }(\alpha=\mathbf{0 . 7 1 0} \text {; AVE }=\mathbf{0 . 4 9 6}) \\
\text { Haski-Leventhal (2013) }\end{array}$ & 0.657 & 0.608 & \\
\hline $\begin{array}{l}\text { Please indicate your level of agreement on the following in regards to your } \\
\text { employer's involvement in the community }(1=\text { strongly disagree...5=strongly } \\
\text { agree): }\end{array}$ & & & \\
\hline $\begin{array}{l}\text { CS-1 It is important for me to work for a company that is highly involved in } \\
\text { the community }\end{array}$ & & & ---- \\
\hline CS-2* Work and giving should be separate & & & 0.713 \\
\hline $\begin{array}{l}\text { CS-3* Volunteering and donating money are an individual choice and should } \\
\text { not be part of my company's community engagement program }\end{array}$ & & & 0.685 \\
\hline $\begin{array}{l}\text { CS-4* My company engages with the community primarily for image and } \\
\text { reputation }\end{array}$ & & & 0.687 \\
\hline $\begin{array}{l}\text { CS-5* My company engages with the community primarily to please } \\
\text { employees }\end{array}$ & & & 0.631 \\
\hline $\begin{array}{l}\text { CS-6 My company engages with the community primarily to help make a } \\
\text { difference }\end{array}$ & & & 0.439 \\
\hline $\begin{array}{l}\text { Competence through Corporate Volunteering ( } \alpha=\mathbf{0 . 7 9 6 ;} \text { AVE }=\mathbf{0 . 6 2 4}) \\
\text { Cnaan and Goldberg-Glen (1991) }\end{array}$ & 0.770 & 0.769 & \\
\hline $\begin{array}{l}\text { How important were the following reasons in your decision to join workplace } \\
\text { volunteering }(1=\text { not important...5=very important): }\end{array}$ & & & \\
\hline IM-1 It makes work more meaningful to me & & & 0.537 \\
\hline It provides an opportunity to use my professional skills to help others & & & 0.803 \\
\hline It provides an opportunity to develop new skills & & & 0.860 \\
\hline It provides an opportunity to network and meet other people & & & 0.774 \\
\hline $\begin{array}{l}\text { Relatedness through Corporate Volunteering }(\alpha=0.714 ; \text { AVE }=0.543) \\
\text { Cnaan and Goldberg-Glen }(1991)\end{array}$ & 0.627 & 0.616 & \\
\hline $\begin{array}{l}\text { How important were the following reasons in your decision to join workplace } \\
\text { volunteering }(1=\text { not important...5=very important): }\end{array}$ & & & \\
\hline EM-1 Friends and colleagues volunteer and I like being part of the team & & & 0.810 \\
\hline EM-2 My boss volunteers & & & 0.697 \\
\hline It is good to know that a lot of people can do more together & & & 0.716 \\
\hline EM-4 It is fun [to be part of the volunteering social group] & & & 0.616 \\
\hline $\begin{array}{l}\text { Affective Commitment }(\boldsymbol{\alpha}=\mathbf{0 . 8 1 8} ; \text { AVE }=\mathbf{0 . 5 8 9}) \\
\text { Meyer, Smith, and Allen }(1993)\end{array}$ & 0.824 & 0.813 & \\
\hline $\begin{array}{l}\text { The following questions deal with your general attitudes towards your } \\
\text { workplace (1=strongly disagree...5=strongly agree): }\end{array}$ & & & \\
\hline AC-1 I would be very happy to spend the rest of my career with this company & & & 0.675 \\
\hline AC-2 I really feel as if this organization's problems are my own & & & 0.532 \\
\hline AC-3* I do not feel a strong sense of "belonging" to my organization & & & 0.809 \\
\hline AC-4* I do not feel “emotionally attached” to this organization & & & 0.864 \\
\hline AC-5* I do not feel like "part of the family" in my organization & & & 0.824 \\
\hline
\end{tabular}


APPENDIX A (Cont.)

\begin{tabular}{|c|c|c|c|}
\hline Scales and Items & $\begin{array}{c}\text { Spearman } \\
\text { Brown }\end{array}$ & $\begin{array}{l}\text { Gutmann } \\
\text { Split-half }\end{array}$ & $\begin{array}{l}\text { Factor } \\
\text { Loading }\end{array}$ \\
\hline $\begin{array}{l}\text { Job Satisfaction }(\boldsymbol{\alpha}=\mathbf{0 . 8 1 3} ; \mathbf{A V E}=\mathbf{0 . 4 8 8}) \\
\text { Hertzberg }(1959,1963)\end{array}$ & 0.797 & 0.788 & \\
\hline $\begin{array}{l}\text { The following questions deal with your general attitudes towards yc } \\
\text { workplace (1=very unsatisfied...5=very satisfied): }\end{array}$ & & & \\
\hline JS-1 Your role & & & 0.734 \\
\hline Your salary and other terms & & & 0.586 \\
\hline Your relationships with others in the workplace & & & 0.672 \\
\hline Your achievements & & & 0.687 \\
\hline Being part of the organization your work for & & & 0.809 \\
\hline Leisure activities your employer initiates & & & 0.635 \\
\hline JS-7 The organization's social responsibility and sustainability & & & 0.634 \\
\hline
\end{tabular}

Notes: CFA: $\chi^{2}=1021.177, \mathrm{df}=253, \mathrm{CFI}=0.924, \mathrm{TLI}=0.910, \mathrm{IFI}=0.924, \mathrm{RMSEA}=0.051, \mathrm{SRMR}=0.053$, $\Delta \chi^{2} / \mathrm{df}=4.036, p<.001$.

* Denotes an item that is reverse scored. 


\section{References}

Aguilera, R. V., Rupp, D. E., Williams, C. A., \& Ganapathi, J. (2007). Putting the s back in corporate social responsibility: A multilevel theory of social change in organizations. Academy of Management Review, 32(3), 836-863. doi:10.5465/amr.2007.25275678

Aguinis, H., \& Glavas, A. (2012). What we know and don't know about corporate social responsibility: A review and research agenda. Journal of Management, 38(4), 932-968. doi:10.1177/0149206311436079

Ajzen, I. (1991). The theory of planned behavior. Organizational Behavior and Human Decision Processes, 50(2), 179-211. doi:https://doi.org/10.1016/0749-5978(91)90020-T

Anderson, J. C., \& Gerbing, D. W. (1988). Structural equation modeling in practice: A review and recommended two step approach. Psychological Bulletin, 103(3), 411-423.

Baard, P. P., Deci, E. L., \& Ryan, R. M. (2004). Intrinsic need satisfaction: A motivational basis of performance and weil-being in two work settings1. Journal of Applied Social Psychology, 34(10), 2045-2068. doi:10.1111/j.1559-1816.2004.tb02690.x

Barman, E. (2007). With strings attached: Nonprofits and the adoption of donor choice. Nonprofit and Voluntary Sector Quarterly. doi:10.1177/0899764007303530

Basil, D., Runte, M., Easwaramoorthy, M., \& Barr, C. (2009). Company support for employee volunteering: A national survey of companies in canada. Journal of Business Ethics, 85(2), 387-398. doi:10.1007/s10551-008-9741-0

Bidee, J., Vantilborgh, T., Pepermans, R., Huybrechts, G., Willems, J., Jegers, M., \& Hofmans, J. (2013). Autonomous motivation stimulates volunteers' work effort: A self-determination theory approach to volunteerism. VOLUNTAS: International Journal of Voluntary and Nonprofit Organizations, 24(1), 32-47. doi:10.1007/s11266-012-9269-x

Blunch, N. (2008). Introduction to structural equation modelling using spss and amos. Thousand Oaks, CA: Sage Publication.

Bollen, K. A., \& Stine, R. A. (1992). Bootstrapping goodness-of-fit measures in structural equation models. Sociological Methods \& Research, 21(2), 205-229.

Borzaga, C., \& Tortia, E. (2006). Worker motivations, job satisfaction, and loyalty in public and nonprofit social services. Nonprofit and Voluntary Sector Quarterly, 35(2), 225-248. doi:10.1177/0899764006287207

Brammer, S., Millington, A., \& Rayton, B. (2007). The contribution of corporate social responsibility to organizational commitment. The International Journal of Human Resource Management, 18(10), 1701-1719. doi:10.1080/09585190701570866

Clary, E. G., Snyder, M., Ridge, R. D., Copeland, J., Stukas, A. A., Haugen, J., \& Miene, P. (1998). Understanding and assessing the motivations of volunteers: A functional approach. Journal of Personality and Social Psychology, 74(6), 1516-1530. doi:http://psycnet.apa.org/doi/10.1037/0022-3514.74.6.1516

Clary, E. G., Snyder, M., \& Stukas, A. A. (1996). Volunteers' motivations: Findings from a national survey. Nonprofit and Voluntary Sector Quarterly, 25(4), 485-505. doi:10.1177/0899764096254006

Cnaan, R. A., \& Goldberg-Glen, R. S. (1991). Measuring motivation to volunteer in human services. The Journal of Applied Behavioral Science, 27(3), 269-284. doi:10.1177/0021886391273003

Crites, S. L., Fabrigar, L. R., \& Petty, R. E. (1994). Measuring the affective and cognitive properties of attitudes: Conceptual and methodological issues. Personality and Social Psychology Bulletin, 20(6), 619-634. doi:10.1177/0146167294206001 
de Gilder, D., Schuyt, T. M., \& Breedijk, M. (2005). Effects of an employee volunteering program on the work force: The abn-amro case. Journal of Business Ethics, 61(2), 143-152. doi:10.1007/s10551-005-7101-x

Deci, E. L., \& Ryan, R. M. (1985). The general causality orientations scale: Self-determination in personality. Journal of Research in Personality, 19(2), 109-134. doi:http://dx.doi.org/10.1016/0092-6566(85)90023-6

Deci, E. L., \& Ryan, R. M. (2000). The "what" and "why" of goal pursuits: Human needs and the selfdetermination of behavior. Psychological Inquiry, 11(4), 227-268. doi:10.1207/S15327965PLI1104_01

Diamantopoulos, A., \& Winklhofer, H. M. (2001). Index construction with formative indicators: An alternative to scale development. Journal of Marketing Research, 38(2), 269-277. doi:10.1509/jmkr.38.2.269.18845

Dury, S., De Donder, L., De Witte, N., Buffel, T., Jacquet, W., \& Verté, D. (2014). To volunteer or not: The influence of individual characteristics, resources, and social factors on the likelihood of volunteering by older adults. Nonprofit and Voluntary Sector Quarterly, 44(6), 1107-1128. doi:10.1177/0899764014556773

Fornell, C., \& Larcker, D. F. (1981). Evaluating structural equation models with unobservable variables and measurement error. Journal of Marketing Research, 18(1), 39-50. doi:10.2307/3151312

Gagné, M. (2003). The role of autonomy support and autonomy orientation in the engagement of prosocial behavior. Motivation and Emotion, 27, 199-223.

Gagné, M., \& Deci, E. L. (2005). Self-determination theory and work motivation. Journal of Organizational Behavior, 26(4), 331-362. doi:10.1002/job.322

Grant, A. M. (2007). Relational job design and the motivation to make a prosocial difference. Academy of Management Review, 32(2), 393-417. doi:10.5465/amr.2007.24351328

Grant, A. M. (2008). Does intrinsic motivation fuel the prosocial fire? Motivational synergy in predicting persistence, performance, and productivity. Journal of Applied Psychology, 93(1), 48-58. doi:10.1037/0021-9010.93.1.48

Grant, A. M. (2012). Giving time, time after time: Work design and sustained employee participation in corporate volunteering. Academy of Management Review, 37(4), 589-615. doi:10.5465/amr.2010.0280

Grant, A. M., Dutton, J. E., \& Rosso, B. D. (2008). Giving commitment: Employee support programs and the prosocial sensemaking process. Academy of Management Journal, 51(5), 898-918. doi:10.5465/amj.2008.34789652

Greguras, G. J., \& Diefendorff, J. M. (2009). Different fits satisfy different needs: Linking personenvironment fit to employee commitment and performance using self-determination theory. Journal of Applied Psychology, 94(2), 465.

Hair, J. F., Black, W., Babin, B., \& Anderson, R. (2010). Multivariate data analysis: A global perspective (7th ed.). Upper Saddle River, New Jersey, US: Prentice Hall.

Haivas, S., Hofmans, J., \& Pepermans, R. (2012). Self-determination theory as a framework for exploring the impact of the organizational context on volunteer motivation. Nonprofit and Voluntary Sector Quarterly, 41(6), 1195-1214. doi:doi:10.1177/0899764011433041

Handy, F., Cnaan, R. A., Brudney, J. L., Ascoli, U., Meijs, L. C. M. P., \& Ranade, S. (2000). Public perception of "who is a volunteer": An examination of the net-cost approach from a crosscultural perspective. Voluntas: International Journal of Voluntary and Nonprofit Organizations, 11(1), 45-65. doi:10.1023/a:1008903032393

Haski-Leventhal, D. (2013). Employee engagement in csr: The case of payroll giving in australia. Corporate Social Responsibility and Environmental Management, 20(2), 113-128. doi:10.1002/csr.1287 
Haski-Leventhal, D., \& Cnaan, R. A. (2009). Group processes and volunteering: Using groups to enhance volunteerism. Administration in Social Work, 33(1), 61-80. doi:10.1080/03643100802508635

Haski-Leventhal, D., Meijs, L. C. P. M., \& Hustinx, L. (2010). The third-party model: Enhancing volunteering through governments, corporations and educational institutes. Journal of Social Policy, 39(01), 139-158. doi:doi:10.1017/S0047279409990377

Haski-Leventhal, D., Oppenheimer, M., Holmes, K., Lockstone-Binney, L., Alony, I., \& Ong, F. (2018). The conceptualization of volunteering among nonvolunteers: Expanding using the net-cost approach to expand definitions and dimensions of volunteering. Nonprofit and Voluntary Sector Quarterly, 0899764018768078. doi:10.1177/0899764018768078

Haski-Leventhal, D., Roza, L., \& Meijs, L. P. M. (2015). Congruence in corporate social responsibility: Connecting the identity and behavior of employers and employees. Journal of Business Ethics, 1-17. doi:10.1007/s10551-015-2793-z

Herzberg, F. (1966). Work and the nature of man. Cleveland: World Publishing.

Herzberg, F., Mausner, B., \& Snyderman, B. B. (1959). The motivation to work (2nd ed.). New York: John Wiley.

Heslin, P. A., \& Ochoa, J. D. (2008). Understanding and developing strategic corporate social responsibility. Organizational Dynamics, 37(2), 125-144.

Hu, L., \& Bentler, P. (1999). Cutoff criteria for fit indexes in covariance structure analysis: Conventional criteria versus new alternatives. Structural Equation Modeling, 6, 1-55.

Kotler, P., \& Lee, N. (2005). Corporate social responsibility: Doing the most good for your company and your cause. Hoboken, NJ: John Wiley \& Sons Inc.

Koufteros, X. A., Rawski, G. E., \& Rupak, R. (2010). Organizational integration for product development: The effects on glitches, on-time execution of engineering change orders, and market success. Decision Sciences, 41(1), 49-80.

Liu, G., Eng, T.-Y., \& Ko, W.-W. (2013). Strategic direction of corporate community involvement. Journal of Business Ethics, 115(3), 469-487. doi:10.1007/s10551-012-1418-z

McDonald, R. E. (2007). An investigation of innovation in nonprofit organizations: The role of organizational mission. Nonprofit and Voluntary Sector Quarterly, 36(2), 256-281. doi:10.1177/0899764006295996

Meyer, J. P., Allen, N. J., \& Smith, C. A. (1993). Commitment to organizations and occupations: Extension and test of a three-component conceptualization. Journal of Applied Psychology, 78(4), 538-551. doi:10.1037/0021-9010.78.4.538

Mirvis, P. (2012). Employee engagement and csr: Transactional, relational, developmental approaches. California Management Review, 54(4), 93-117.

Morris, S. A. (1997). Internal effects of stakeholder management devices. Journal of Business Ethics, 16(4), 413-424. doi:10.1023/A:1017900209031

Nunnally, J. C., \& Bernstein, I. (1994). Psychometric theory (3rd ed.). New York: McGraw-Hill.

Oostlander, J., Güntert, S. T., Schie, S. v., \& Wehner, T. (2014). Leadership and volunteer motivation. Nonprofit and Voluntary Sector Quarterly, 43(5), 869-889. doi:doi:10.1177/0899764013485158

Paço, A. d., \& Nave, A. C. (2013). Corporate volunteering: A case study centred on the motivations, satisfaction and happiness of company employees. Employee Relations, 35(5), 547-559. doi:doi:10.1108/ER-12-2012-0089

Peterson, D. K. (2004). The relationship between perceptions of corporate citizenship and organizational commitment. Business \& Society, 43(3), 296-319. doi:10.1177/0007650304268065

Plewa, C., Conduit, J., Quester, P., \& Johnson, C. (2015). The impact of corporate volunteering on csr image: A consumer perspective. Journal of Business Ethics, 127(3), 643-659. doi:10.1007/s10551-014-2066-2 
Podsakoff, P. M., MacKenzie, S. B., Lee, J. Y., \& Podsakoff, N. P. (2003). Common method biases in behavioral research: A critical review of the literature and recommended remedies. Journal of Applied Psychology, 88(5), 879-903. doi:10.1037/0021-9101.88.5.879

Rodell, J. (2013). Finding meaning through volunteering: Why do employees volunteer and what does it mean for their jobs? Academy of Management Journal. doi:10.5465/amj.2012.0611

Rodell, J., Breitsohl, H., Schröder, M., \& Keating, D. J. (2016). Employee volunteering: A review and framework for future research. Journal of Management, 42(1), 55-84. doi:10.1177/0149206315614374

Rupp, D. E., Shao, R., Thornton, M. A., \& Skarlicki, D. P. (2013). Applicants' and employees' reactions to corporate social responsibility: The moderating effects of first-party justice perceptions and moral identity. Personnel Psychology, 66(4), 895-933. doi:10.1111/peps.12030

Ryan, R. M., \& Deci, E. L. (2000). Self-determination theory and the facilitation of intrinsic motivation, social development, and well-being. American Psychologist, 55(1), 68-78. doi:10.1037/0003-066X.55.1.68

Ryan, R. M., \& Deci, E. L. (2001). To be happy or to be self-fulfilled: A review of research on hedonic and eudemonic wellbeing. In S. Fiske (Ed.), Annual review of psychology (Vol. 52, pp. 141-166). Palo Alto, CA: Annual Reviews.

Shrout, P. E., \& Bolger, N. (2002). Mediation in experimental and nonexperimental studies: New procedures and recommendations. Psychological Methods, 7(4), 422-445. doi:10.1037//1082989x.7.4.422

Skudiene, V., \& Auruskeviciene, V. (2012). The contribution of corporate social responsibility to internal employee motivation. Baltic Journal of Management, 7(1), 49-67. doi:doi:10.1108/17465261211197421

Steers, R. M. (1981). Introduction to organizational behavior. Santa Monica, Cal.: Goodyear Publishing.

Sundeen, R. A., \& Raskoff, S. A. (1994). Volunteering among teenagers in the united states. Nonprofit and Voluntary Sector Quarterly, 23(4), 383-403. doi:doi:10.1177/089976409402300407

Trevino, L. K., \& Nelson, K. A. (2004). Managing business ethics: Straight talk about how to do it right (3rd ed.). New York, NY: John Wiley and Sons.

Valentine, S., \& Fleischman, G. (2008). Ethics programs, perceived corporate social responsibility and job satisfaction. Journal of Business Ethics, 77(2), 159-172. doi:10.1007/s10551-0069306-z

Van den Broeck, A., Ferris, D. L., Chang, C.-H., \& Rosen, C. C. (2016). A review of selfdetermination theory's basic psychological needs at work. Journal of Management. doi:10.1177/0149206316632058

van Schie, S., Gautier, A., Pache, A.-C., \& Güntert, S. T. (2018). What keeps corporate volunteers engaged: Extending the volunteer work design model with self-determination theory insights. Journal of Business Ethics. doi:10.1007/s10551-018-3926-y

Vansteenkiste, M., Neyrinck, B., Niemiec, C. P., Soenens, B., De Witte, H., \& Van den Broeck, A. (2007). On the relations among work value orientations, psychological need satisfaction and job outcomes: A self-determination theory approach. Journal of Occupational and Organizational Psychology, 80(2), 251-277. doi:10.1348/096317906X111024

Williams, L. J., Hartman, N., \& Cavazotte, F. (2010). Method variance and marker variables: A review and comprehensive cfa marker technique. Organizational Research Methods, 13(3), 477-514. doi:10.1177/1094428110366036

Wilson, J. (2012). Volunteerism research: A review essay. Nonprofit and Voluntary Sector Quarterly. doi:10.1177/0899764011434558 
Figures and Tables

FIGURE 1A

Model for Affective Commitment

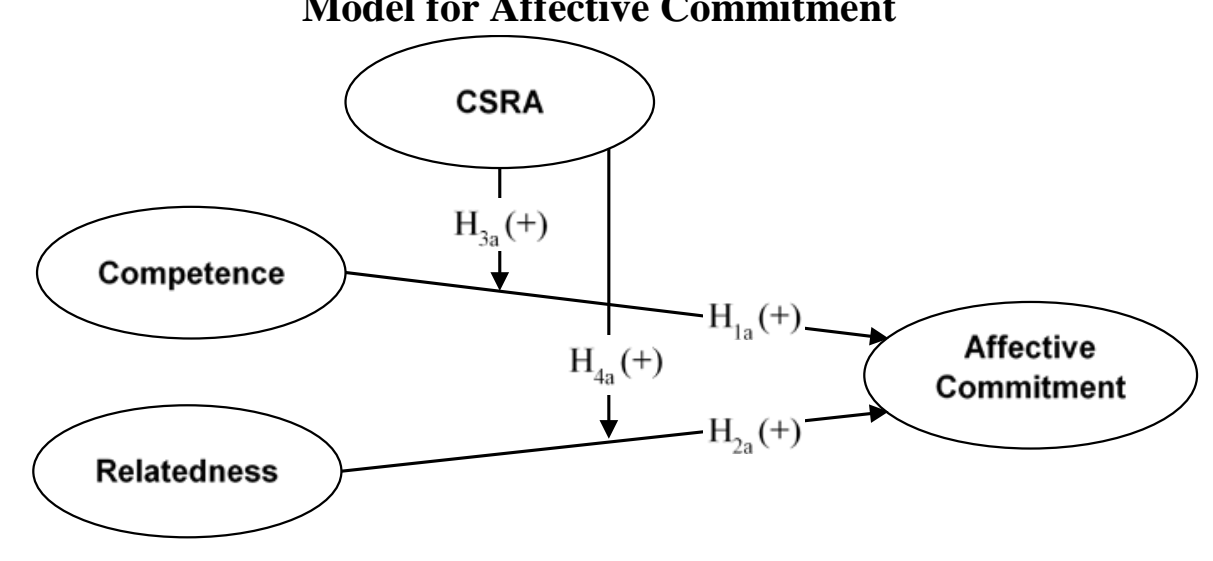

FIGURE 2A

Linear Regression Results Model for Affective Commitment

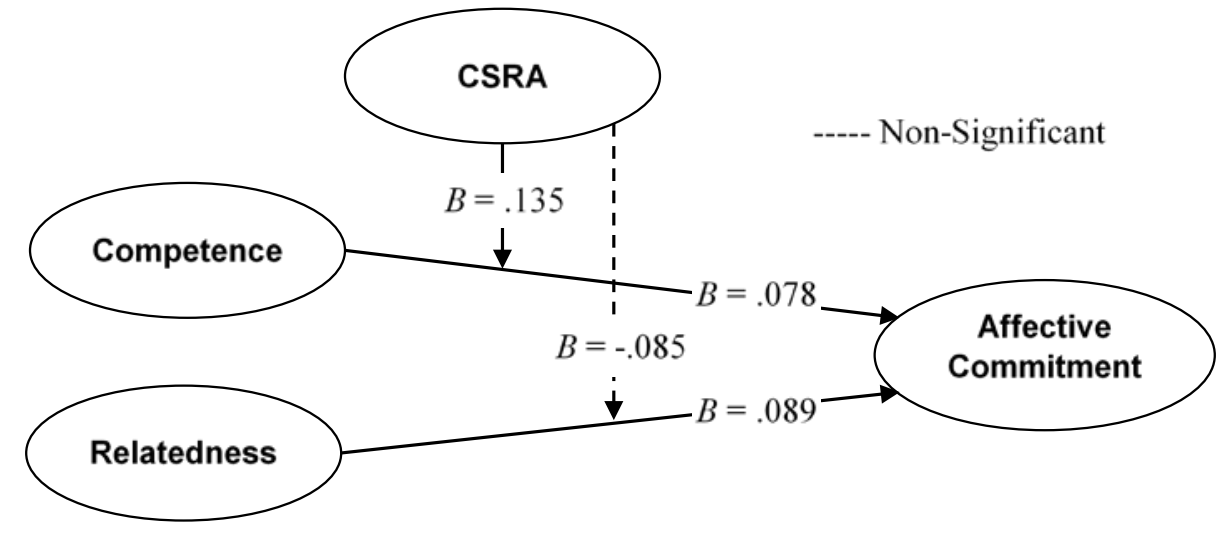

FIGURE 1B

Model for Job Satisfaction

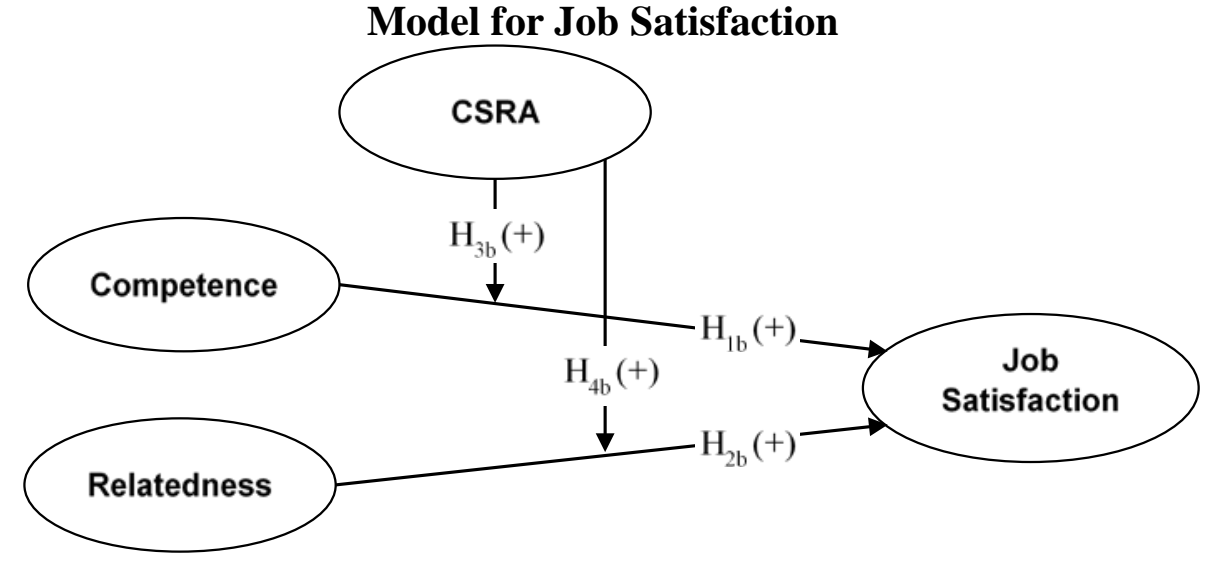

FIGURE 2B

Linear Regression Results Model for Job Satisfaction

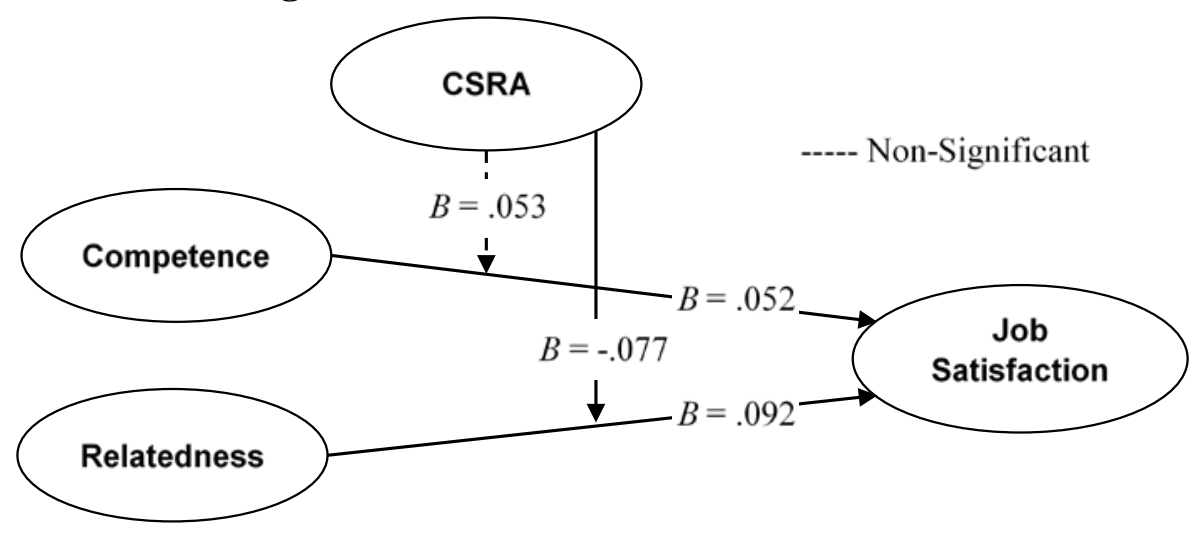


FIGURE 3A

Interaction between CSR Attitudes and Competence on Affective Commitment

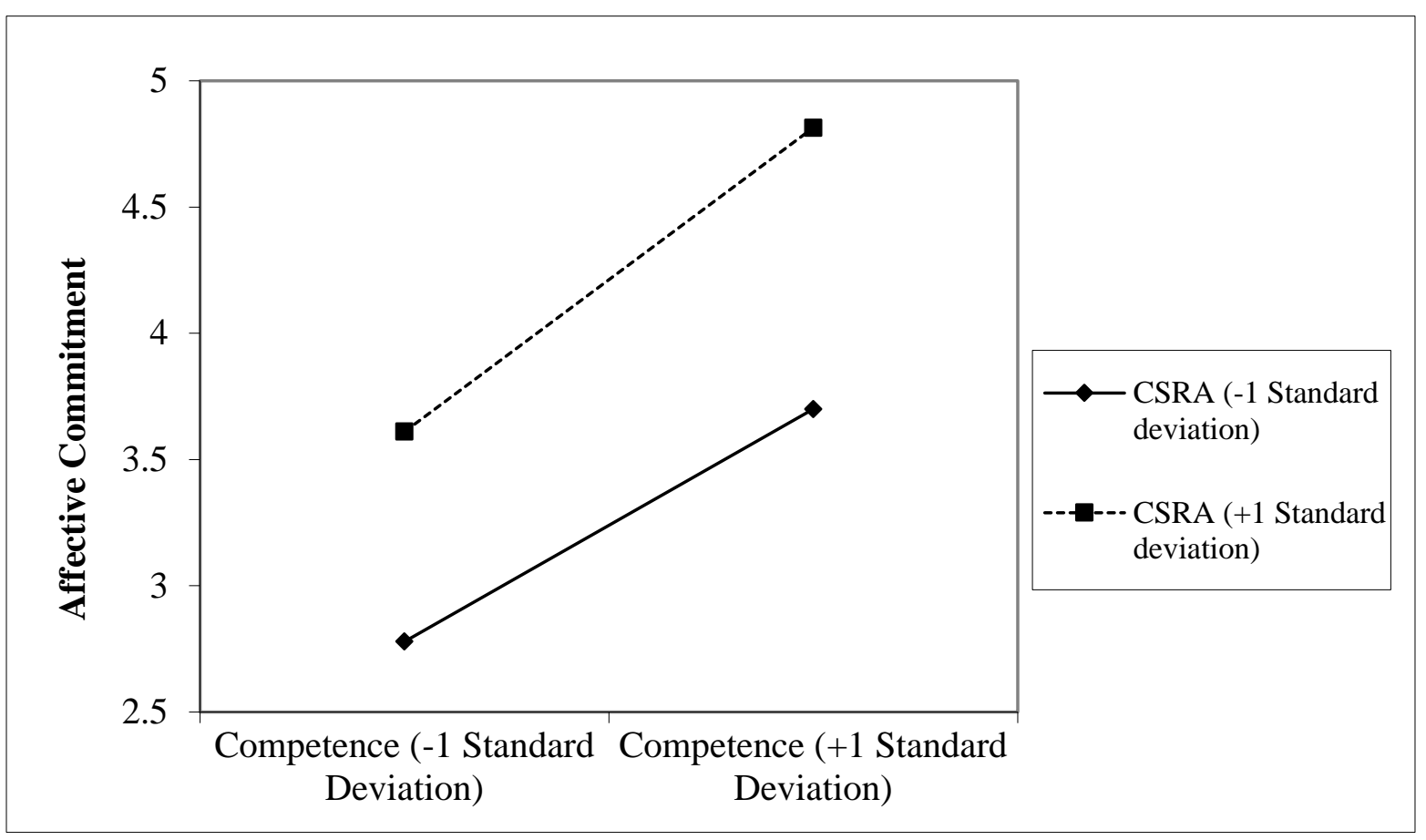


FIGURE 3B

Interaction between CSR Attitudes and Relatedness on Job Satisfaction

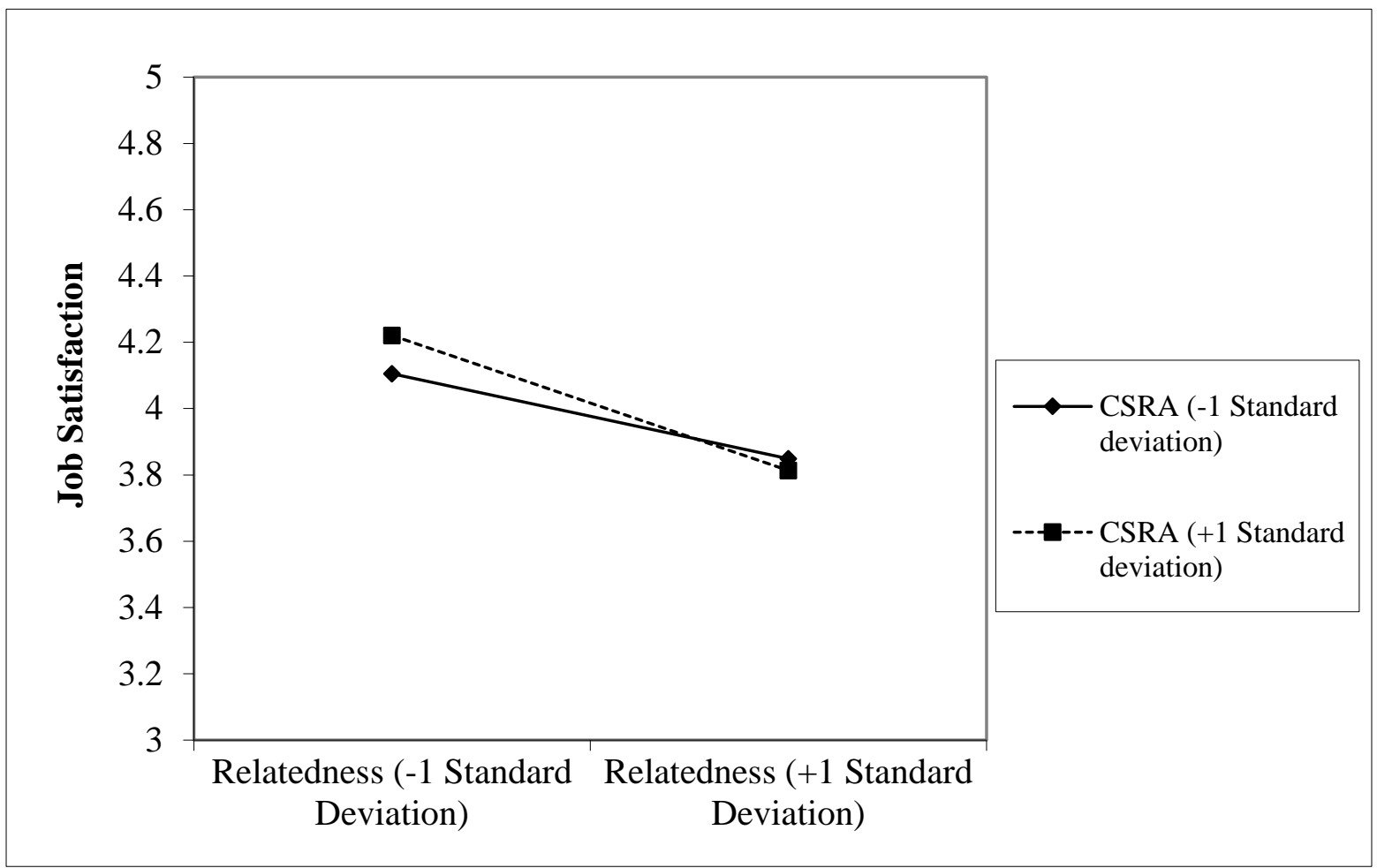


TABLE 1

Antecedent and dependent variables juxtaposed with volunteer and non-volunteer data

\begin{tabular}{lccccc|c}
\hline Dependent Variable & $\mathrm{B}$ & Std. Error & $\mathrm{t}$-value & F-value & $p$-value & Correlation $^{\mathrm{a}}$ \\
\hline Job Satisfaction & .102 & .017 & 5.933 & 35.202 & .001 & $.093^{* *}$ \\
Affective Commitment & .117 & .023 & 5.073 & 25.738 & .001 & $.080^{* *}$ \\
CSR Attitudes & .129 & .018 & 7.280 & 53.002 & .001 & $.114^{* *}$ \\
\hline
\end{tabular}

Notes: ${ }^{\text {a }}$ Correlation with the volunteering variable (non-volunteers $=0$, volunteers $=1$ ).

${ }^{* *} p<.01$ 
TABLE 2

Means, Standard Deviations, and Pearson Correlation Coefficients

\begin{tabular}{|c|c|c|c|c|c|c|c|c|c|c|c|c|c|}
\hline \multicolumn{2}{|c|}{ Variable } & Mean & SD & 1 & 2 & 3 & 4 & 5 & 6 & 7 & 8 & 9 & 10 \\
\hline 1. & Employee Age (Ctrl) & 42.83 & 9.40 & & & & & & & & & & \\
\hline 2. & Employee Gender (Ctrl) & 1.47 & 0.49 & $.12^{* *}$ & & & & & & & & & \\
\hline 3. & Employee Salary (Ctrl) & 3.05 & 0.94 & $.13^{* *}$ & $.28^{* *}$ & & & & & & & & \\
\hline 4. & Job Hours (Ctrl) & 43.98 & 10.75 & .06 & $.26^{* *}$ & $.32^{* *}$ & & & & & & & \\
\hline 5. & Volunteer Hours (Ctrl) & 26.30 & 30.39 & .00 & .01 & .01 & .04 & & & & & & \\
\hline 6. & Employee Education (Ctrl) & 2.54 & 1.10 & $-.23^{* *}$ & $.09^{* *}$ & $.23^{* *}$ & $.07^{*}$ & -.03 & & & & & \\
\hline 7. & CSR Attitudes & 3.70 & 0.57 & $-.08^{*}$ & $-.18^{* *}$ & -.02 & $-.08^{* *}$ & .04 & .02 & & & & \\
\hline 8. & Competence through CV & 3.44 & 0.92 & $-.12^{* *}$ & $-.19^{* *}$ & $-.07^{*}$ & -.04 & $.11^{* *}$ & .05 & $.30^{* *}$ & & & \\
\hline 9. & Relatedness through CV & 3.22 & 0.86 & $-.12^{* *}$ & $-.11^{* *}$ & $-.08^{* *}$ & -.05 & $-.08^{*}$ & -.03 & $.16^{* *}$ & $.40^{* *}$ & & \\
\hline 10. & Affective commitment & 3.53 & 0.77 & .04 & -.05 & .05 & .03 & .05 & -.01 & $.37^{* *}$ & $.21^{* *}$ & $.18^{* *}$ & \\
\hline 11. & Job Satisfaction & 3.74 & 0.58 & .00 & $-.10^{* *}$ & .02 & -.04 & .02 & .01 & $.38^{* *}$ & $.20^{* *}$ & $.22^{* *}$ & $.58^{* *}$ \\
\hline
\end{tabular}

Notes: $\mathrm{n}=911 . * p<.05, * * p<.01$. Ctrl $=$ Control Variable.

Employee Gender (1) = female, $(2)=$ male. 
TABLE 3

Multivariate Linear Regression

\begin{tabular}{|c|c|c|c|c|c|c|c|}
\hline & \multicolumn{3}{|c|}{ Affective Commitment } & \multicolumn{4}{|c|}{ Job Satisfaction } \\
\hline & $\begin{array}{c}\text { Model } 1 \\
\text { Control } \\
\text { Variables }\end{array}$ & $\begin{array}{c}\text { Model } 2 \\
\text { Direct } \\
\text { Effects }\end{array}$ & $\begin{array}{l}\text { Model } 3 \\
\text { Full } \\
\text { Model }\end{array}$ & $\begin{array}{c}\text { Model } 1 \\
\text { Control } \\
\text { Variables }\end{array}$ & $\begin{array}{c}\text { Model } 2 \\
\text { Direct } \\
\text { Effects }\end{array}$ & $\begin{array}{c}\text { Model } 3 \\
\text { Full } \\
\text { Model }\end{array}$ & \\
\hline \multicolumn{8}{|l|}{ Direct Effects } \\
\hline CSR Attitudes & & $.403^{* * *}$ & $.389 * * *(.041)$ & & $.282 * * *$ & $.283 * * *$ & $(.031)$ \\
\hline Competence (H1 a \& H1b) & & $.081 * *$ & $.078 * * \quad(.029)$ & & $.047^{*}$ & $.052 *$ & $(.022)$ \\
\hline Relatedness $\left(\mathrm{H} 2_{\mathrm{a}} \& \mathrm{H} 2_{\mathrm{b}}\right)$ & & $.076^{* *}$ & $.089 * * \quad(.030)$ & & $.096 * * *$ & $.092 * * *$ & $(.023)$ \\
\hline \multicolumn{8}{|l|}{ Moderation Effects } \\
\hline CSRA x Competence (H3a \& H3 $\left.{ }_{b}\right)$ & & & $.135 * * *(.043)$ & & & .053 & $(.032)$ \\
\hline CSRA x Relatedness (H4a \& H4b) & & & $-.085^{\dagger} \quad(.050)$ & & & $-.077^{*}$ & $(.038)$ \\
\hline \multicolumn{8}{|l|}{ Control Variables } \\
\hline Employee Gender & $-.133 *$ & .002 & $(.052)$ & $-.127 * *$ & -.032 & -.030 & $(.040)$ \\
\hline Employee Age & .032 & $.059 *$ & $(.026)$ & .008 & .031 & $.033^{\dagger}$ & $(.020)$ \\
\hline Employee Salary & .023 & .013 & $(.028)$ & .028 & .022 & .024 & $(.021)$ \\
\hline Employee Education & .005 & -.004 & $(.022)$ & .016 & .012 & .014 & $(.017)$ \\
\hline Job Hours Worked & .004 & $.005^{\dagger}$ & $(.003)$ & -.003 & -.002 & -.002 & $(.002)$ \\
\hline Volunteer Hours Worked & .001 & .001 & $(.001)$ & .001 & .001 & .001 & $(.001)$ \\
\hline Adjusted $\mathrm{R}^{2}$ & .004 & .147 & .155 & .010 & .149 & .153 & \\
\hline F-Statistic & 1.556 & $53.388 * * *$ & $57.290 * * *$ & $2.551^{*}$ & $52.669 * * *$ & $55.022 * * *$ & \\
\hline$\Delta$ Adjusted $\mathrm{R}^{2}$ & & .143 & .008 & & .139 & .004 & \\
\hline$\Delta$ F-Statistic & & $51.832 * * *$ & $3.902 * *$ & & $50.118 * * *$ & $2.353^{\dagger}$ & \\
\hline
\end{tabular}

Notes: $\mathrm{n}=911 ;{ }^{\dagger} \mathrm{p}<0.10,{ }^{*} \mathrm{p}<0.05,{ }^{* *} \mathrm{p}<0.01,{ }^{* * *} \mathrm{p}<0.001$; Reported coefficients are unstandardized; Std. errors are in parentheses 